\title{
Donald Woods Winnicott
}

\author{
D Ambuja \\ Post Graduate, Dept. of Psychiatry, SVS Medical College \& Hospital, Mahbubnagar, Telangana, India
}

*Corresponding Author: D Ambuja

Email: dachaambuja@gmail.com

\begin{abstract}
Donald Woods Winnicott was an English Paediatrician and a Psychoanalyst who contributed to the field of Object Relations Theory and Developmental Psychology.Winnicott described himself as a disturbed adolescent, reacting against his own self-restraining "goodness" trying to assuage the dark moods of his mother, which were the seeds of self-awareness and became the basis of his interest in working with troubled young people. ${ }^{1}$ Winnicott's focus highlighted the very start of life as his psychoanalytic clinical findings illuminated the significance of the parental role in early object relations. ${ }^{4}$ Thus, at the core of Winnicott's contributions are the Parent-Infant Relationship, ${ }^{4}$ True Self And False Self and Play And Reality. ${ }^{6}$
\end{abstract}

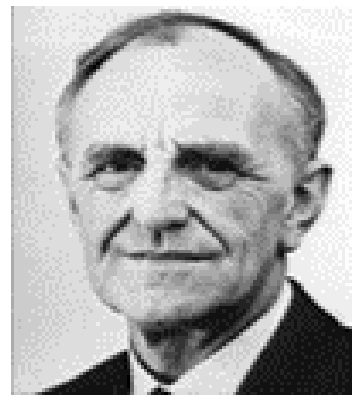

\section{Introduction}

Donald Woods Winnicott was born on 7 April 1896 in Plymouth, Devon. He began pre-clinical studies at Jesus College, Cambridge in 1914 but, with the onset of World War I, his studies were interrupted when he was made a medical trainee at the temporary hospital in Cambridge. In 1917, he joined the Royal Navy as a medical officer on the destroyer HMS Lucifer. He studied in clinical medicine at St Bartholomew's Hospital Medical College in London where he learnt from his mentor the art of listening carefully when taking medical histories from patients, a skill which was foundation for his practice as a Psychoanalyst. He completed his medical studies in $1920 .^{1}$

In 1923, he marriedAlice Buxton Winnicott (born Taylor). She had "severe psychological difficulties" and he arranged his own therapy for her to address the difficulties created due to the condition. He obtained a post as Physician at the Paddington Green Children's Hospital in London, where he worked as a Paediatrician and Child Psychoanalyst for 40 years. In 1923 he began a ten-year psychoanalysis with James Strachey, and in 1936a second analysis with Joan Riviere. ${ }^{2}$

During the Psychoanalytic movement between the Freudians and the Kleinians, Winnicott belonged to a "Middle Group" of the British Psychoanalytical Society (later called the "Independent Group"), along with Ronald Fairbairn, Michael Balint, Masud Khan, John Bowlby, Marion Milner, and Margaret Little. ${ }^{2}$

During the Second World War, he served as Consultant Psychiatrist to the evacuee program where he met and worked with Clare Britton, a psychiatric social worker who became his colleague in treating children displaced from their homes by wartime evacuation. He divorced his first wife in 1949 and married Clare Britton (1907-1984) in $1951 .^{3}$

\section{Three distinct phases of Winnicott's work}

According to Winnicott, Psychoanalysis is a study of human nature as well as a therapeutic method. With concept of a sense of self as the center which evolves in the context of a facilitating environment i.e. the parent-infant relationship. ${ }^{4}$

- $\quad$ Phase One 1935 - 1944 - The environment-individual set-up

'There's no such thing as an infant.' This was built on Freud's recognition of the transference as a manifestation of psychic transmission related to the infant's early psychic history. Because of the infant's dependency on the object his evolving sense of self inevitably incorporated the parents' emotional transmissions. ${ }^{4}$

- $\quad$ Phase Two 1945 - 1960 - Transitional Phenomena

It is the interpsychic-intrapsychic dynamics of the subject's journey towards the capacity to distinguish Me from Not-me i.e. the capacity to symbolize. The young infant's use of a 'transitional object', was the way in which the infant worked out how to separate and develop an autonomous sense of self though founded on the internalization of the mother's care. ${ }^{4}$ Transitional objects like security blankets, special dolls or toys, and other sentimental items can help a child feel safe and secure. It begins the process of individuation, or differentiation of self from others. ${ }^{1}$

\section{- $\quad$ Phase Three 1960 - 1971 - The use of an Object}

The object had survived the infant's intense instinctual communications. It offers an alternative way of understanding the fate of human aggression without resorting to the notion of a death instinct. ${ }^{4}$

\section{True Self, False Self}

He believed that the false self was a mannerly, orderly, external self that enables a person to fit into society and the true self is capable of creativity. Play helps a person develop this true self by which clients gain awareness into their authentic emotional selves. He encouraged play through creative outlets, such as art, sports, or movement. 
He believed the therapist could help a client reveal the uninhibited child within and rediscover a true sense of being. ${ }^{11}$

True Self is a sense of being alive and real in one's mind and body, having feelings that are spontaneous and unforced. This experience of aliveness is what allows people to be genuinely close to others, and to be creative. ${ }^{11}$

False Self is a defence, a kind of mask of behaviour that complies with others' expectations. He thought in health, a False Self was what allowed one to present a "polite and mannered attitude" in publicwhich develops through the process of introjection. ${ }^{11}$

\section{The Theory of Parent-Infant Relationship}

i. An examination is made of infancy; this is not the same as an examination of primitive mental mechanisms. ${ }^{(5)}$

ii. The main feature of infancy is dependence; this is discussed in terms of the holding environment. ${ }^{(5)} \mathrm{He}$ referred "holding" to the supportive environment that a therapist creates for a client. Like nurturing and caring behavior a mother engages in with her child results in a sense of trust and safety. He believed that this "holding environment" was critical to the therapeutic environment and could be created through the therapist's direct engagement with a client. The delinquent child - he believed that antisocial behaviors developed from a person having been deprived of a holding environment in childhood and from feelings of insecurity. ${ }^{1}$

iii. Any study of infancy must be divided into two parts:

a. Infant development facilitated by good-enough maternal care; A good-enough parent is well enough attuned and responsive to protect the baby with an illusion of omnipotence, or being all-powerful. ${ }^{5}$

b. Infant development distorted by maternal care that is not good enough. ${ }^{5}$

iv. The infant ego can be said to be weak, but in fact is strong because of the ego support of maternal care. Where maternal care fails the weakness of the infant ego becomes apparent. ${ }^{5}$

v. Processes in the mother (and in the father) bring about, in health, a special state in which the parent is orientated to the infant, and is thus in a position to meet the infant's dependence. There is a pathology of these processes. $^{5}$

vi. Attention is drawn to the various ways in which these conditions inherent in what is here termed the holding environment can or cannot appear in the transference if at a later date the infant should come into analysis. ${ }^{5}$

\section{Playing and Reality}

Winnicott considered that playing was the key to emotional and psychological well-being. Two of the techniques whereby Winnicott used play in his work. ${ }^{6}$

1. Squiggle game - drawing a shape for the child to play with and extend (or vice versa) - a practice extended by his followers into that of using partial interpretations as a 'squiggle' for a patient to make use of. ${ }^{10}$
2. Spatula game - placing a spatula (tongue depressor) within the child's reach for him to play with. He considered that "if he is just an ordinary baby he will notice the attractive object and he will reach for it, then in the course of a little while he will discover what he wants to do with it". From the child's initial hesitation in making use of the spatula, he derived his idea of the necessary 'period of hesitation' in childhood (or analysis), which makes possible a true connection to the toy, interpretation or object presented for transference. ${ }^{10}$

\section{Honors}

- Leading member of the British Independent Group of the British Psychoanalytical Society. ${ }^{2}$

- President of the British Psychoanalytical Society twice (1956-1959 and 1965-1968). ${ }^{4}$

\section{Publications}

- Clinical Notes on Disorders of Childhood (London: Heinemann, 1931). ${ }^{7}$

- Getting To Know Your Baby (London: Heinemann, 1945). ${ }^{7}$

- The Child and the Family (London: Tavistock, 1957). ${ }^{7}$

- The Child and the Outside World (London: Tavistock, 1957). ${ }^{7}$

- Collected Papers: Through Paediatrics to Psychoanalysis (London: Tavistock, 1958). ${ }^{7}$

- The Child the Family and the Outside World (London: Pelican Books, 1964). ${ }^{7}$

- The Family and Individual Development (London: Tavistock, 1965). ${ }^{7}$

- Maturational Processes and the Facilitating Environment: Studies in the Theory of Emotional Development (London: Hogarth Press, 1965). ${ }^{7}$

- $\quad$ Playing and Reality (London: Tavistock, 1971). ${ }^{7}$

- Therapeutic Consultation in Child Psychiatry (London: Hogarth Press, 1971). ${ }^{7}$

- The Piggle: An Account of the Psychoanalytic Treatment of a Little Girl (London: Hogarth Press, 1971) ISBN 0-140-1466-79. ${ }^{7}$

\section{Posthumous}

- Deprivation and Delinquency (London: Tavistock, 1984). ${ }^{7}$

- Human Nature (Winnicott Trust, 1988) notebooks. ${ }^{7}$

- The Collected Works of D. W. Winnicott (Oxford University Press, 2016). ${ }^{7}$

His theoretical writings emphasised empathy, imagination, and, in the words of philosopher Martha Nussbaum, who has been a proponent of his work, "the highly particular transactions that constitute love between two imperfect people.". 7 


\section{Other Achievements}

- He gave over sixty talks on the radio between 1943 and 1966. His first series of talks in 1943 was titled "Happy Children". ${ }^{8}$

- Published over 200 papers with his work been cited in 15,642 articles. $^{4}$

- Squiggle Foundation established by Clare after his death. ${ }^{9}$

He died on 25 January 1971, following the last of a series of heart attacks and was cremated in London. Clare Winnicott oversaw the posthumous publication of several of his works. ${ }^{9}$

\section{References}

1. https://www.goodtherapy.org/famous-psychologists/donaldwinnicott.html

2. https://independentpsychoanalysistrust.uk/
3. Kanter J. The Untold Story of Clare and Donald Winnicott: How Social Work Influenced Modern Psychoanalysis. Clin Soc Work J. 2000;28(3):245-61.

4. https://psychoanalysis.org.uk/our-authors-and-theorists/donaldwoods-winnicott

5. DW Winnicott - The Theory of Parent-Infant Relationship. Int J Psycho-Anal. 1960;41:585-95.

6. DW Winnicott - Playing And Reality.

7. https://www.thriftbooks.com/a/dw-winnicott.

8. BBC RADIO 4 Archive 4, The idea of 'good-enough mother',https://www.bbc.co.uk.

9. DW Winnicotthttps://www.oxforddnb.com

10. http://squiggle-foundation.org

11. Daehnert C. The False Self as a Means of Disidentification: A Psychoanalytic Case Study. Contemp Psychoanal. 1998;34:251-71.

How to cite this article: Ambuja D. Donald Woods Winnicott. Telangana J Psychiatry. 2020;6(1):91-93. 